\title{
DAMPAK AKSI EKSTRIMISME DAN TERORISME TERHADAP COLLECTIVE PUNISHMENT PADA WANITA DAN ANAK-ANAK
}

\author{
Muhamad Tisna Nugraha \\ Institut Agama Islam Negeri (IAIN) Pontianak \\ tisnanugraha2014@yahoo.com
}

\begin{abstract}
Abstrak: Pada beberapa dekade terakahir, nama Islam sering kali dicatut dengan aksi-aksi gerakan ekstrimis dan teroris yang terjadi diberbagai penjuru dunia. Penggunan nama dan simbol-simbol ajaran agama tersebut tidak hanya berdampak pada pelaku dan korbannya, melainkan juga terhadap pihak-pihal yang justru tidak terlibat maupun tahu menahu akar persoalannya. Sehingga seseorang ataupun kelompok tertentu bisa saja mengalami apa yang disebut dengan collective punishment, dimana seseorang atau kelompoknya dihukum secara kolektif bukan karena kesalahan sendiri, melainkan karena kesalahan orang lain. Korban utama dari collective punishmet ini sebagian besar adalah kaum perempuan dan anak-anak. Mereka adalah sasaran empuk berbagai bentuk tindakan kekerasan fisik maupun psikis, hal ini karena sifat mereka yang cenderung lemah, dan tidak berdaya dalam melakukan perlawanan terhadap serangan yang datang, apa lagi jika dilakukan secara kolektif. Sehingga di tempat-tempat publik seperti lingkungan kerja, lingkungan masyarakat, bahkan di sekolah, perempuan dan anak-anak rentan mengalami collective punishmet mulai dalam bentuk kekerasan verbal, kekerasan fisik, hingga pada aksi pembunuhan.
\end{abstract}

Kata Kunci: Ekstrimis, Teroris dan Collective Punishment

\section{Pendahuluan}

Seiring maraknya pemberitaan aksi-aksi gerakan ektrimis dan teroris yang mengunakan simbol ajaran agama tertentu. Hal tersebut secara langsung maupun tidak langsung berdampak terhadap dinamika kehidupan sosial masyarakat diberbagai penjuru dunia. Kurangnya pengertian dan pemahaman terhadap hukum, serta adanya kelompok-kelompok anti Islam yang memanfaatkan situasi untuk melancarkan kampanye-kampanye hitam. Pada akhirnya, melahirkan hukuman kolektif atau collective punishment ditengah-tengah masyarakat.

Implikasi dari kejadian tersebut, dibeberapa negara muncul gerakan Islamophobia yang menganggap Islam sebagai sebuah ancaman bersama dan harus diintimidasi, sehingga umat Islam dilarang untuk melaksanakan shalat, berpuasa di bulan ramadhan, mendirikan masjid, menggunakan jilbab serta larangan-larangan bersifat tendisisus lainnya. Sementara pernikahan sesama jenis, pornografi dan porno aksi justru malah dilegalkan.

Tidak hanya di mancanegra, di Indonesia ketika terjadi penangkapan terduga teroris. Media lokal dan sosial secara gencar telah membentuk indentifikasi pelaku teroris melalui jenggot dan isterinya yang memakai cadar. Hal ini mengarahkan pada stigma bahwa orang berjenggot dan bercadar indentik dengan pelaku teroris. Padahal pemberitaan-pemberitaan yang mencatut indentitas agama seperti ini, dikemudian hari hanya melahirkan imagi dan benih-benih collective punishment serta permusuhan yang baru dan tidak menyelasaikan akar persoalan terorisme sesungguhnya. 
Lebih lanjut, korban dari semua aksi gerakan ektrimis dan teroris tidak hanya menimbulkan kerugian maupun kematian bagi pelaku dan target sasarannya. Melainkan juga berdampak pada perempuan dan anak-anak umat Islam. Faktor gender, usia, kekuatan dan tingkat kemampuan, menjadikan perempuan dan anak-anak lebih rentan menjadi korban collective Punishment dibandingkan pria dewasa. Perempuan dan anak-anak dipandang sebagai simbol keberlangsungan sebuah kelompok, sehinga bagi para pelaku collective punishment, mereka menjadi sasaran empuk proxy violence, atau suatu kekerasan yang dilakukan karena sasaran utama tidak ada.

Pada akhirnya, perempuan dan anak-anak pelaku gerakan ekstrimis dan teroris harus menanggung resiko dari kejahatan yang tidak dilakukannya. Suatu hukuman sosial, berupa sindiran, pengucilan dan penolakan, yang seolah menjadikan stigma dari kehadiran mereka sebagai musuh bersama atas warisan dosa yang dilakukan suami, orang tua, atau individu dari komunitas masyarakatnya. Padahal disisi lain, perempuan dan anak-anak ini harus bekerja keras mencari nafkah untuk membiayai hidup seharihari. Hingga, tak jarang, sebagian besar dari mereka lebih memilih untuk hijrah ke tempat yang lebih jauh.

\section{Ekstrimisme dan Terorisme Terhadap Collective Punishment Wanita dan Anak}

Ekstrimisme, Terorisme dan Collective
Punishment

Muhammad Abed al-Jabiri (dalam Rahmat, 2008) menggunakan istilah ekstrimisme Islam untuk menggambarkan kelompok Islam ekstrim yang biasanya mengarahkan permusuhan dan perlawanannya pada gerakan-gerakan Islam "tengah" atau "moderat". Gerakan kaum ekstrimis biasanya tertuju pada upaya merebut kekuasaan dari pemerintahan yang syah dengan menunggangi isu-isu agama sebagai isu ideology gerakannya. Jika dimasa lampau gerakan-gerakan ekstrimis klasik hanya berkutat pada tataran aqidah, maka gerakan ekstrimis kontemporer telah mampu untuk menunjukan eksistensi hingga pada tataran syari'ah dengan melakukan perlawanan ekstrim hingga pada aksi terorisme.

Meminjam pendapat Prayitno Ramelan (2009), terorisme adalah sebuah mazhab atau aliran kepercayaan melalui pemaksaan kehendak, guna menyuarakan pesannya. Tindakan mazhab ini menjurus pada kekerasan, kebrutalan bahkan pembunuhan yang dilakukan dengan metode konvensional hingga modern, baik perorangan ataupun kelompok. Ketika ekstrimisme dan terorisme dijadikan ideologi dan misi dakwah, maka ajaran Islam sebenarnya telah diselewengkan serta menjadi alat untuk melegitimasi gerakan dan pikiran destruktif. Sehingga, dalam pengertian ini masyarakat biasa mau tidak mau menjadi bagian dari masyarakat yang disebut Hobbes sebagai homo homini lupus (manusia adalah serigala bagi sesamanya).

Kehadiran golongan ekstrimis dan teroris yang menggunakan simbol agama sebenarnya adalah jawaban dari krisis kepercayaan pada lembaga-lembaga agama, politik dan negara yang dianggap tidak lagi berkompeten dalam melaksanakan tugasnya. Sehingga, wacana maupun isu ektrimis yang biasa mereka usung adalah persoalan ketidakadilan, kesenjangan, kemiskinan, keboborokan akhlak serta harapan akan kesejahteraan. Hal inilah yang kemudian memudahkan kelompok ini mendapatkan simpatisan dan loyalis dari dari masyarakat muslim yang tidak mempelajari Islam secara komprehensif.

Tidak semua aksi dan gerakan kelompok ektrimis maupun teroris berhasil mencapai citacita dan tujuan yang diharapkan. Sebagian besar diantaranya gagal di tengah jalan melalui proses 
Tetapi tidak sedikit pula diantara mereka yang berhasil melarikan diri, kemudian memilih hidup dipengasingan ataupun menjadi buronan.

Bagi para pelaku gerakan ekstrimis dan teroris, persoalan ini dapat dianggap selesai. Namun, bagi keluarga terutama perempuan dan anak-anak muslim, persoalan ini tidak berakhir begitu saja. Terlebih aksi yang dilakukan pelaku terjadi dalam kawasan ataupun negara dimana minoritas muslim tinggal serta mencari penghidupan. Dengan demikian, tindakan pelaku eksatrimis dan teroris justru tidak mendatangkan mafaat melainkan mudharat yang pada akhirnya mendatangkan apa yang dikenal sebagai hukuman kolektif atau collective punishment. Suatu hukuman yang tidak hanya berdampak pada keluarga pelaku namun juga kelompok ras, etnis dan agama tertentu yang pada dasarnya tidak memiliki keterkaitan langsung.

Collective punishment dapat diartikan sebagai hukuman atau pembalasan masyarakat secara kolektif terhadap anggota keluarga, teman, tetangga, komunitas, etnis dan lain-lain yang menjadi tempat asal ataupun identitas pelaku. $\mathrm{Hal}$ ini sebagaimana pendapat Leslie Alan Horvitz dan Christopher Catherwood (2006) yang menyatakan, collective punishment is a form of reprisal that seeks to inflict pain on a particular group or population crimes supposedly carried out by one or more of its members, because it means imposing punishment on many innocent people for actions of a few collective punishment is outlawed by international law.

Dalam ajaran Islam, collective punishment dikisahkan dalam sebuah riwayat bersumber dari Rasulullah saw., (dalam Al-Albani, 2002), yang artinya:

"Dari Abu Hurairah bahwa Rasulullah bersabda, "dulu ada seorang nabi yang singgah di bawah sebatang pohon. Lalu dia digigit seokor semut. Maka, dia memerintahkan agar barng-barangnya diangkat. Lalu, semut itu dikeluarkan dari dalamnya, kemudian dia memerintahkan agar sarangnya dibakar, maka sarangnyapun dibakar. Lalu, Allah mewahyukan kepaddanya, 'Apakah karena seekor semut (dalam jalur lain, 'Karena engkau digigit seekor semut lalu engaku membakar satu umat yang bertasbih kepada Allah!?').”

Pada banyak kasus collective punishment berakhir pada tindakan kekerasan, yakni sebuah tindakan yang dilakukan untuk melawan orang lain atau kelompok lain yang diakibatkan oleh konflik dan perbedaan. Adapun indikator dari tindak kekerasan dimaksud, antara lain: pertama, kekerasan terbuka yakni kekerasan yang dapat dilihat atau diamati secara langsung, seperti kerusuhan, tawauran atau hal-hal lain yang berkaitan dengan eksperesi tindakan yang berbentuk fisik. Kedua, kekerasan tertutup yakni kekerasan yang dilakukan secara diam-diam, sembunyi-sembunyi atau tidak dilakukan secara langsung, seperti melakukan ancaman, intimidasi, atau simbol-simbol tekanan psikis lain yang menyebabkan korban merasa takut atau tertekan. Ketiga, kekerasan agresif (offensive) yakni kekerasan yang dilakukan untuk mendapatkan sesuatu secara paksa seperti dalam bentuk perampasan, pencurian, pemerkosaan atau bahkan pembunuhan yang kesemuanya sudah dikategorikan sebagai perbuatan kriminal. Keempat, kekerasan defensif (defensive) yakni kekerasan yang dilakukan sebagai tindakan perlindungan terhadap kekuatan lain yang akan mengancam, seperti melakukan pemblokiran.

Dari tingkat (level) intensitas suatu kekerasan bisa meningkat dari kekerasan ringan atau potensi menjadi kekerasan tingkat sedang maupun berlanjut pada kekerasan tingkat berat, berupa tindak kriminal. Kekerasan disebut dalam bentuk potensi, 
nama baik seseorang, dan ancaman atau intimidasi. Bila kekerasan tertutup berubah menjadi konflik terbuka, unjuk rasa berubah menjadi bentrok, ancaman berubah menjadi tindakan nyata, dan kekerasan defensif menjadi ofensif, maka saat itu juga potensi berubah menjadi kekerasan.

Dari berbagai penjelasan di atas, perempuan dan anak-anak adalah sasaran berbagai acaman tindakan kekerasan sebagaimana dimaksud. Selain karena sifatnya yang lemah, perempuan dan anak-anak cenderung tidak berdaya melakukan perlawanan terhadap serangan fisik maupu psikis yang terjadi terhadap diri mereka. Sehingga, collective punishment sangat rentan terjadi terlebih dengan ketiadaaan perlindungan maupun jaminan terhadap keselamatan dan kesejahteraan mereka dimasa-masa yang akan datang.

\section{Collective Punishment Pada Wanita dan Anak-Anak}

Collective punishment dapat muncul dalam bentuk penolakan masyarakat secara kolektif terhadap perempuan dan anak-anak yang menjadi pelaku maupun terduga perbuatan ekstrimis dan teroris. Beberapa tekanan yang dialami adalah berupa bentuk kekerasan verbal yang terwujud dalam bentuk tindak tutur seperti mengejek, memaki, mengusir, menghujat, mengancam, dan membuat malu. Bahkan tidak jarang kekerasan verbal tersebut diikuti dengan kekerasan fisik berupa perusakan properti, penganiyaan, pemerkosaan, hingga pembunuhan.

Council on American-Islamic relations (CAIR) dalam laporan tahun 2012 sebagaimana dikutip Noorsaid Harun (2005), menyebutkan bahwa sejak peristiwa 11 September 2001, tak kurang dari 1.717 pengaduan tentang hate crime dan diskriminasi terhadap warga muslim yang telah mereka terima. Dari jumlah tersebut, bentuk hate crime yang paling banyak adalah pelecehan seksual di depan umum (public harassment) sebanyak 372 kasus, termasuk diantaranya yang menimpa Samar Kaukab (22) mahasiswi Ohio Satet University, yang dipaksa telanjang untuk digeledah oleh petugas bandara hanya lantaran ia berjilbab, pengiriman suratsurat bernada ancaman dan kebencian (hate mail) sebanyak 315 kasus, penyerangan secara fisik dan perusakan property sebanyak 289 kasus, pembunuhan 11 kasus, diskriminasi di tempat kerja 166 kasus, diskriminasi di air port 191 kasus, intimidasi di sekolah 74 kasus, dan intimidasi dilakukan oleh FBI dan Polisi sebanyak 224 kasus.' Hal ini belum termasuk yang terjadi di Inggris, Perancis dan negaranegara minoritas muslim lainnya.

Selain laporan lembaga CAIR tersebut, M. Nur Kholis Setiawan dan Djaka Soetapa (2010) menyebutkan hasil survey nasional yang diadakan pada tahun 2003 oleh Pusat Riset Pew dan Forum Agama dan Kehidupan Publik Pew, menyebutkan bahwa persentase orang Amerika yang memandang kurang baik terhadap Islam meningkat satu persen menjadi $34 \%$ dari tahun 20002 dan 2003, lalu meningkat lagi dua persen menjadi $36 \%$ pada tahun 2005 . Streyotipe inilah yang kemudian menjadikan orang Islam di Amerika pada saat itu dianggap dapat mendorong tindak kekekerasan jika dibandingkan dengan agama lain.

Selain terjadi di Amerika, collective punishment juga terjadi pada perempuan dan anak-anak Islam diberbagai negara dalam bentuk intimidasi atau perlakuan yang bersifat memaksa. Hal ini sebagaimana terjadi Perancis, di tahun 2015 dimana kaum perempuan mendapatkan pelarangan menggunakan hijab di tempat-tempat umum setelah sebelumnya pemberlakuan aturan ini terjadi di sekolah-sekolah. Selain itu, di Xinjiang, China otoritas setempat pada bulan

${ }^{1}$ Hate Crime adalan suatu tindak kejahatan yang dilakukan terhadap korban karena motivasi-motivasi yang berasal dari rasial, warna kulit, etnisitas, agama, 
ramadhan $1437 \mathrm{H} / 2016 \mathrm{M}$, secara resmi menyatakan tidak memberikan toleransi pada umat Islam untuk mengerjakan ibadah puasa. Bahkan di Indonesia pada awal tahun 2016 ribuan anggota eks-Gafatar (Gerakan Fajar Nusantara) terpaksa diusir dari Kalimantan Barat karena dianggap sebagai bagian dari organisasi aliran sesat. Namun yang patut diperhatikan dari semua kasus tersebut adalah kesemua orang yang menjadi korban aksi-aksi tersebut mayoritasnya adalah perempuan dan anak-anak. Berbagai collective punishment selanjutnyaberada pada titik, dimana metode dan praktik hukuman yang dilakukan berdampak sangat mahal, karena beberapa atau banyak orang dihukum justru oleh karena kesalahan orang lain bukan karena kesalahannya sendiri.

Pada negara berkembang, collective punishment saat ini belum banyak mengarah pada tindakan pembantaian masal ataupun genosida seperti yang terjadi pada negara-negara tertinggal di benua Afrika. Namun benih-benih ini telah tampak terlihat jelas terjadi dibeberapa sektor kehidupan, diantaranya: Pertama, collective punishment in school, dimana seseorang di bullying dengan tindakan berupa dipermalukan, dipalak place (dimintai uang), atau dianiaya (dipukuli). Kedua, collective punishment in the work, dimana seseorang mengalami diskriminasi dalam promosi jabatan, hak-hak tenaga kerja termasuk dalam hal cuti dan upah. Ketiga, collective punishment in society, dimana seseorang diacuhkan, dihina, ditolak dan bahkan diusir dari lingkungan masyarakatnya, dan keempaat, collective punishment intenational law, dimana suatu negara sebagaimana yang terjadi pada Palestina, ketika penindasan dan pembantaian militer Israel terhadap warga sipil tak bersenjata dianggap bukan sebagai kejahatan perang dan tidak diadili hukum internasional.

Lebih lanjut, selain berbagai bentuk dan sektor kehidupan dimana seseorang mendapatkan collective punishment, perlu juga di garis bawahi bahwa sebagian korban justru memilih untuk tidak melaporkan tindakan tersebut kepada pihak yang berwajib. Hal ini karena otoritas berwenang yang juga mencurigai korban sebagai bagian dari pelaku serta adanya keyakinan dari korban collective punishment kalau apa yang mereka lakukan adalah sesuatu yang sia-sia . Berdasarkan penjelasan ini, apa yang terjadi pada korban collective punishment perlu mendapatakan penanganan yang berbeda jika dibandingkan pada kasus-kasus perlindungan perempuan dan anak pada umumnya. Mereka perlu ditangani pihak ataupun lembaga yang bersifat independence, dilindungi serta didampingi agar mereka yang pada saat ini menjadi korban tidak menjadi pelaku di masa-masa yang akan datang. Sebagai akibat dari ketidakadilan yang telah diterima mereka di masa lalu.

\section{Collective Punishment dalam Perspektif Hukum dan Agama}

Andre Ata Ujan (2009) menyatakan bahwa, menghukum orang yang tidak bersalah demi menegakkan tertib sosial atau kebaikan umum adalah tindakan yang merendahkan martabat dan kemulian manusia. Apalagi menurut Oksidelfa Yanto (2010) dalam perkara pidana ada adagium yang menarik untuk dicermati, yaitu bahwa lebih baik melepaskan seribu orang bersalah dari pada menghukum satu orang yang tidak bersalah. Namun disisi lain, tindakan membiarkan pelaku pergi tanpa hukuman adalah suatu penyangkalan bahwa si pelaku atau si terhukum juga adalah subyek moral. Sehingga dari sini lahirlah masyarakat utilitarian meskipun hal ini berbeda dengan collective punishment yang lahir dari persepsi masyarakat, sebagaimana diungkapkan oleh Kantian (dalam Wattimena, 2008):

“... Bagi utilataris, penghukuman hanya 
bagi lebih banyak orang. Bagi Kantian, kegagalan dalam menghukum pelaku kejatan sama jahatnya dengan menghukum orang yang sebenarnya tidak bersalah. Bagi utilitarian, salah atau tidak salahnya pelaku yang dihukum tidaklah menjadi prioritas utama, jika dibandingkan dengan persepsi masyarakat. Persepsi masyarakatlah yang menentukan apakah tindak penghukuman itu akan memberikan kebahagiaan yang lebih besar atau tidak. Menghukum orang yang tidak bersalah, tetapi dianggap bersalah menghasilkan kebahagiaan yang lebih besar dari pada menghukum orang yang bersalah, tetatpi tidak dianggap bersalah. walaupun situasi tampak tidak adil bagi si pelaku, hasil keseluruhan akan memberikan kebahagian yang lebih besar.

Berdasarkan pandangan tersebut di atas, apabila hukum hanya bertumpu pada persepsi dan argumentasi masyarakat dan tujuan satusatunya hanyalah pada mengejar apa yang disebut dengan utilitarian atau kepuasan semata, maka vonis hukuman yang ada hanyalah menciptakan kambing hitam untuk dijadikan korban hukuman yang pada akhirnya melunturkan asas praduga tak bersalah. Hal inilah yang sudah diperingatkan Allah swt., dalam firmannya:

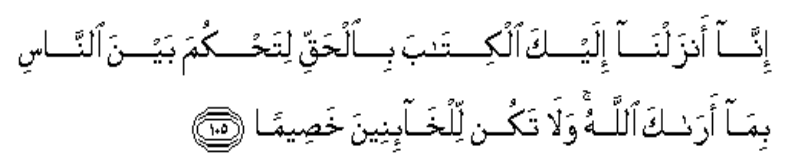

"Sesungguhnya Kami telah menurunkan Kitab kepadamu dengan membawa kebenaran, supaya kamu mengadili antara manusia dengan apa yang telah Allah wahyukan kepadamu, dan janganlah kamu menjadi penantang (orang yang tidak bersalah), karena (membela) orang-orang yang khianat" (QS. An-Nisa (4): 105).

Lebih lanjut, syariat Islam juga tidak membenarkan hukuman yang dilakukan tanpa niat atau ketidaksengajaan, maupun hukuman yang hanya didasarkan pada sangkaan, serta dalam kondisi paceklik seperti yang terjadi di masa kepemimpinan Umarn bin Khattab. Hal demikian juga berlaku pada orang yang cacat mental tidak dapat dikenai tanggung jawab hukum, dan karenanya tidak dapat dihukum. Orang yang membunuh semata-mata untuk menyelamatkan diri, atau pembunuhan menjadi satu-satunya cara untuk menyelamatkan hidupnya, tidak pantas dihukum sebagai pelaku kejahatan. Hal ini sebagaimana hadits Rasulullah SAW., (dalam Sulaiman, 2005) yang artinya: "Pencatatan atas amal perbuatan itu tidak dilakukan karena tiga perkara: Karena tidur (tidak sadar) hingga terbangun, karena sakit hingga sembuh dan karena masih kecil hingga dewasa."

\section{Simpulan}

Berdasarkan berbagai penjelasan di atas, tindakan ekstrimis dan teroris dapat membentuk collective Punishment yang berdampak kepada kaum lemah seperti wanita dan anak-anak. Hukuman yang diberikan masyarakat kepada korban collective punishment seringkali tidak memiliki hubungan langsung dengan tindakan yang dilakukan oleh pelaku dan kelompoknya. Hukum tersebut adalah tindakan keadilan masyarakat tanpa batasan. Bahkan, dalam banyak kasus collective punishment tidak memiliki kontrol sosial yang jelas atas tindakannya untuk menuntut pembayaran atau balas dendam. Tidak mengherankan collective punishment berujung pada kematian atau bahkan pembantaian secara masal pada suatu komunitas tertentu. Meskipun disisi lain collective punishment diperlukan untuk mencegah perilaku anggota masyarakat untuk tidak melakukan perbuatan yang sama, maupun sebagai katalisator melakukan perubahan.

Otoritas berwenang dan pemerhati 


\section{2-52 | HARKAT: Media Komunikasi Islam Tentang Gender dan Anak, 12 (1), 2016}

memperhatikan dan mengangkat masalah collective punishment, ke dalam isu-isu sentral yang perlu segera mendapat perhatian, perlindungan serta pendampingan. Termasuk melakukan zero tolerance policy terhadap aksi yang merugikan pihak-pihak yang sebenarnya tak bersalah dan tidak tahu menahu tentang persoalan yang dilakukan orang lain. Karena dampak dari suatu tindakan collective punishment hanya akan melahirkan generasigenerasi ektrimis dan teroris baru.

\section{Daftar Pustaka}

Albani, M. Nashiruddin. 2002. Ringkasan Shahih Bukhari. Jakarta: Gema Insani Press.

Harun, Noorsaid. 2005. Manajemen Sekuriti Muslimah: Pedoman Sekuriti Muslimah dari Intaian Tindakan Kriminal. Solo: Samudera.

Horvitz, Leslie Alan dan Catherwood, Christopher. 2006. Encyclopedia of War Crimes and Genocide. New York: Facts on File.

Qur'an Tajwid. 2006. Jakarta: Maghfirah Pustaka.
Rahmat, M. Imdadun. 2008. Ideologi Politik PKS: Dari Masjid Kampus ke Gedung Parlemen. Yogyajarta: LkiS.

Ramelan, Prayitno. 2009. Intelijen Bertawaf: Teroris Malaysia dalam Kupasan. Jakarta; Grasindo.

Setiawan, M. Nur Kholis dan Soetapa, Djaka. (Ed). 2010. Meniti Kelam Kerukunan: Beberapa Istilah Kunci dalam Islam dan Kristen. Jakarta: Gunung Mulia.

Sulaiman, Umar Al-Asyqar. 2005. Fiqh Niat dalam Ibadah. Jakarata: Gema Insani Press.

Tim Penyusun Kamus Pustaka Bahasa. 2008. Kamus Bahasa Indonesia. Jakarta: Pusat Bahasa.

Ujan, Andre Ata. 2009. Filsafat Hukum. Yogyakarta: Kanisius.

Wattimena, Reza. A. A. 2008. Filsafat dan Sains: Sebuah Pengantar. Jakarta: PT. rasindo.

Yanto, Oksidelfa. 2010. Mafia Hukum: Membongkar Konsfirasi dan Manipulasi Hukum di Indonesia. Jakarta: Raih Asa Sukses. 